\title{
エチレンジアミンパラジウム（II）錯体溶液からの パラジウム電析におよばすタリウムの影響
}

\author{
千田 伸*，瀬畑浩之**，久保田昇***，佐藤栄一**
}

\author{
The Effect of Thallium on Palladium Electrodeposition \\ from Ethylenediamine-Palladium (II) Complex Solutions
}

Shin CHIDA*, Hiroyuki SEBATA**, Noboru KUBOTA*** and Eiichi SATO**

\begin{abstract}
The effect of thallium on palladium electrodeposition was investigated by the addition of thallium ion to ethylenediamine-palladium (II) complex solutions. Thallium ion resulted in underpotential deposition on copper and palladium electrodes and shifted the current-potential curves of the palladium electrodeposition to the more noble side. It also activated the electrodeposition of palladium and in hibited hydrogen evolution, so that the hydrogen content of deposits was decreased. In addition, thallium ion influenced the nucleation and growth processes of crystals so that the crystal size of deposits increased with greater overpotential, and it also changed the morphology of the deposits. Thus it is concluded thallium has catalytic effects on the electrodeposition of palladium.
\end{abstract}

Key Words : Palladium Electrodeposition, Electrocatalysis, Underpotential Deposition, Depolarization

\section{1. 緒言}

バラジゥムは耐食性に優れ，耐摩耗性，展延性に富む など良好な物理的・化学的性質を有して物り，金，銀な

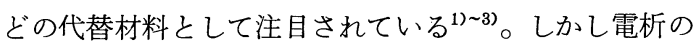
際, 結晶内に水素を吸蔵して電析皮膜の物性が低下する といら久点がある ${ }^{4), 5)}$ 。

ところで, $\mathrm{IIb} \sim \mathrm{Vb}$ 族のヒ素, 鉛, タリウム, ビスマ スなどは, 貴金属電極上に析出して水素発生反応を変化 させたり ${ }^{6)}$ 10)，金の電析反応に対して接触作用 ${ }^{11), 12)}$ 示すなど，貴金属原子との相互作用の大きいことが知ら れている。また，著者らは先に，エチレンジアミンバラ ジウム (II) 錯体溶液からのバラジウムの電析に対して 七素が触媒的に作用し, 電流効率を向上させるとともに 水素吸蔵量を減少させ, 電析物中に微量共析して皮膜を 非晶質化させることを見い出した ${ }^{13), 14) 。 ~}$

本研究では, 酸性溶液中でバラジウム電極の水素発生 の活性サイトに析出し, 水素の発生を㧕制する ${ }^{8), 10)}$ とい われるタリウムに注目した。エチレンジアミンバラジウ

* 宇都宮大学大学院 (厂321 杤木県宇都宮市石井町2753) Graduate School of Utsunomiya Univ. (2753, Ishii machi, Utsunomiya-shi, Tochigi 321)

** 宇都宮大学工学部（テ321 栃木県宇都宮市石井町2753） Fac. of Eng., Utsunomiya Univ. (2753, Ishii -machi, Utsunomiya-shi, Tochigi 321)

*** 熊本県工業技術センター（干862 熊本県熊本市東町3-11） Industrial Research Institute of Kumamoto Prefecture (3-11, Higashi-machi, Kumamoto-shi, Kumamoto 862)
ム（II）錯体溶液にタリウムイオンを添加してバラジウ ムの電析を行い, バラジウムの電析反応, 電析皮膜の水 素吸蔵量や結晶構造などの特性に対するタリウムの影響 を検討した。

\section{2. 実 験 方 法}

\section{1 電解液の調製}

実験に使用した電解液は, 支持電解液として 0.269 $\mathrm{mol} \cdot \mathrm{dm}^{-3} \mathrm{EDTA}-2 \mathrm{Na}, 0.198 \mathrm{~mol} \cdot \mathrm{dm}^{-3} \mathrm{Na}_{2} \mathrm{SO}_{3}$ 水溶液 を用いた。バラジウムはジクロロジアンミンバラジウム $\left(\mathrm{Pd}\left(\mathrm{NH}_{3}\right)_{2} \mathrm{Cl}_{2}\right)$ とェチレンジアミン (en)を次式のよう に反応させ，エチレンバラジゥム錯体 $\left(\mathrm{Pd}(\mathrm{en})_{2}{ }^{2+}\right.$, $0.088 \mathrm{~mol} \cdot \mathrm{dm}^{-3}$ ) として溶液に添加した。タリウムは硫 酸タリウム $\left(\mathrm{Tl}_{2} \mathrm{SO}_{4}, 2.5 \times 10^{-3} \mathrm{~mol} \cdot \mathrm{dm}^{-3}\right)$ として加穴, 電解液 $\left(\mathrm{pH}=8.0,25^{\circ} \mathrm{C}, 250 \mathrm{~cm}^{3}\right)$ を調製した。

$$
\begin{aligned}
& \mathrm{Pd}\left(\mathrm{NH}_{3}\right)_{2} \mathrm{Cl}_{2}+2 \text { en } \\
& \quad \rightarrow \mathrm{Pd}(\mathrm{en})_{2}{ }^{2+}+2 \mathrm{NH}_{3}+2 \mathrm{Cl}^{-}
\end{aligned}
$$

\section{2 皮膜の電析および分極曲線の測定}

電析皮膜の下地基板には無酸素銅 $(99.99 \%)$ 板を用 いた。基板に, 前処理としてバフ研磨, アセトン脱脂, 化学研磨, 酸浸せきを施したのち, 蒸留水で十分洗浄し て試料に供した。皮膜の電析は対極に白金電極, 参照電 極に飽和甘コウ電極 (SCE) を用い, 通過電気量を18 ーロン・ $\mathrm{cm}^{-2}$ として定電位電解法により行った。

カソード分極曲線の測定には容量 $250 \mathrm{~cm}^{3}$ の電解槽を 用いた。アノードに白金線, 試料極には表面積 0.87 $\mathrm{cm}^{2}$ の無酸素銅円板あるいは $\mathrm{Tl}^{+}$を含をない電解液か 
ら Pd を電析させた銅円板を Pt-RDE（回転ディスク電 極）に接合した電極を用い，SCEを参照電極として電 位走査法 (走査速度 $: 1 \mathrm{mV} \cdot \mathrm{s}^{-1}$ ) にて測定した。電解液 は約45分間窒素ガスを吹き込んで溶存酸素を除去し，測 定は窒素ガス雲囲気中で行った。

電析皮膜中の $\mathrm{Tl}$ の共析量は電析物を王水で溶解し， 蒸留水で希釈して ICP 発光分光分析器を用いて分析し 決定した。また，ハラジウム電析の電流効率は電析前後 の重量変化拈よび皮膜の組成から, 水素吸蔵量は $1 \mathrm{~mol} \cdot \mathrm{dm}^{-3} \mathrm{NaOH}$ 水溶液中で電析皮膜を酸化水銀電極 に対して $+0.122 \mathrm{~V}$ に保ち, 吸蔵水素をアノード酸化し た際に流れた電気量から算出した ${ }^{4)}$ 。

\section{3 皮膜の結晶構造と表面観察}

電析皮膜の結晶構造は $\mathrm{X}$ 線回折 $(\mathrm{Cu}-\mathrm{K} \alpha$ 線使用, 管 電圧 $40 \mathrm{kV}$, 管電流 $20 \mathrm{~mA}$ ) により同定した。各回折線 の面指数は，格子定数と面指数との関係式を用いて決定 した ${ }^{15)}$ 。また結晶粒径は回折線の強度が大きく, 読み 取りの誤差の少ない（111）面の半価幅を測定し, Sherrerの式により計算した。加えて走査型電子顕徽鏡 (SEM) により皮膜の表面を観察した。

\section{3. 実験結果および考察}

\section{1 カソード分極曲線}

図 1 拈よび図 2 にエチレンジアミンバラジウム錯体 $\left[\operatorname{Pd}(\mathrm{en})_{2}{ }^{2+}\right]$ 牤よびタリウムイオンを添加した際の, 銅 電極执よびハシラジウム電極に和けるカソード分極曲線を それぞれ示す。銅電極に扣いて（図1），タリウムイオ ンを添加すると, $-0.70 \mathrm{~V}(\mathrm{SCE})$ 付近に還元電流ピー クが生じた。この電位は(2)式 ${ }^{16)}$ からタリウムの析出電 位と考兄られる（曲線 b)。

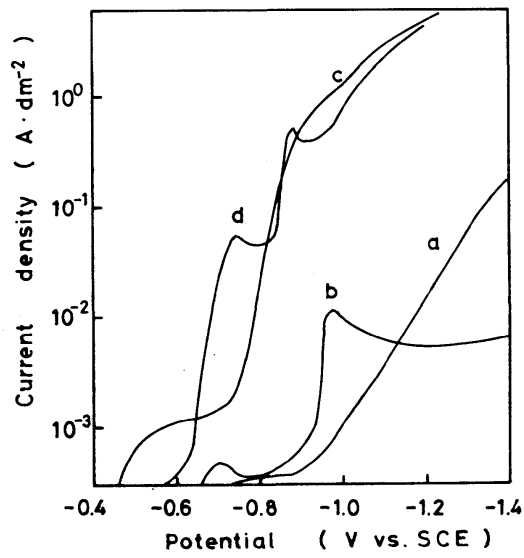

Fig. 1 Cathodic current-potential curves obtained in each solutions on $\mathrm{Cu}$ electrode at $1 \mathrm{mV} \cdot \mathrm{s}^{-1}$.

Solutions ; a : supporting electrolyte, b : $5 \times 10^{-3} \mathrm{~mol} \cdot \mathrm{dm}^{-3} \mathrm{Tl}^{+}$, c : $0.088 \mathrm{~mol} \cdot \mathrm{dm}^{-3} \mathrm{Pd}(\mathrm{en})_{2}{ }^{2+}$, $\mathrm{d}: 0.088 \mathrm{~mol} \cdot \mathrm{dm}^{-8} \mathrm{Pd}(\mathrm{en})_{2}{ }^{2+}+5 \times 10^{-3} \mathrm{~mol} \cdot \mathrm{dm}^{-3} \mathrm{Tl}^{+}$
$\mathrm{Tl}^{+}+\mathrm{e}=\mathrm{T} 1$

$$
\begin{aligned}
E_{\mathrm{SCE}} & =-0.578+0.0591 \log \left(\mathrm{Tl}^{+}\right) \mathrm{V} \\
& =-0.714 \mathrm{~V}\left(\mathrm{Tl}^{+}: 5 \times 10^{-3} \mathrm{~mol} \cdot \mathrm{dm}^{-3}\right)
\end{aligned}
$$

一方, $\operatorname{Pd}(\mathrm{en})_{2}{ }^{2+}$ を添加した場合（曲線 c ）， - 0.75 $\mathrm{V}(\mathrm{SCE})$ 付近から電流が急激に増加してハラジウムと 水素が電析から発生した。

エチレンジアミンパラジウムからバラジウムが析出す る電位は恐らく(3) ${ }^{17), 18)}$ 式から $0.01 \mathrm{~V}(\mathrm{SCE})$ 付近であ るが，実験結果からハラシジウムが盛んに電析するのは一 $0.75 \mathrm{~V}(\mathrm{SCE})$ 付近の電位であった。

$$
\begin{aligned}
& \mathrm{Pd}(\mathrm{en})_{2}{ }^{2+}+2 \mathrm{e}=\mathrm{Pd}+2 \mathrm{en} \\
& E_{\mathrm{SCE}}=-0.050+R T / n \mathrm{~F} \ln \left(\left[\mathrm{Pd}(\mathrm{en})_{2}{ }^{2+}\right] /[\mathrm{en}]^{2}\right) \\
& =0.015 \mathrm{~V}\left(\mathrm{Pd}(\mathrm{en})_{2}{ }^{2+}: 0.088 \mathrm{~mol} \cdot \mathrm{dm}^{-3}\right. \text {, } \\
& \text { en : } 0.024 \mathrm{~mol} \cdot \mathrm{dm}^{-3} \text { ) }
\end{aligned}
$$

さらにタリウムイオンを添加すると（曲線 $\mathrm{d} ）-0.60$ $\mathrm{V}(\mathrm{SCE})$ から電流の急激な増加が開始され, $-0.75 \mathrm{~V}$ (SCE), $-0.87 \mathrm{~V}(\mathrm{SCE})$ 付近に電流ピークが生じた。 このよらに, タリウムイオンの添加はハララジウムの急激 な析出電位を約 $150 \mathrm{mV}$ も貴に移行しハシラジウムの電析 に対して有効な接触作用を示す。

Pd 電極に持ける分極曲線（図 2）も同様であり, 電 解液中にタリウムイオンが存在すると一- $0.70 \mathrm{~V}(\mathrm{SCE})$ よりも卑な電位に存在したバラジウム電析の分極曲線は より貴な電位に移行し，ハラジウムの電析が開始された。 また， $-0.95 \mathrm{~V}(\mathrm{SCE})$ 付近に拈いて，タリウムの析出 が活発になるとともにバラジウムの電析も促進された。

\section{2 電流効率と水素吸蔵量に対するタリウムの影響}

図 3 には定電位電解を行った場合のハラシジウム電析の 電流効率と電析皮膜中のタリウムの共析量を, 図 4 には 電析皮膜の水素吸蔵量を示す。図 $3 \sim 8$ に用いた試料は

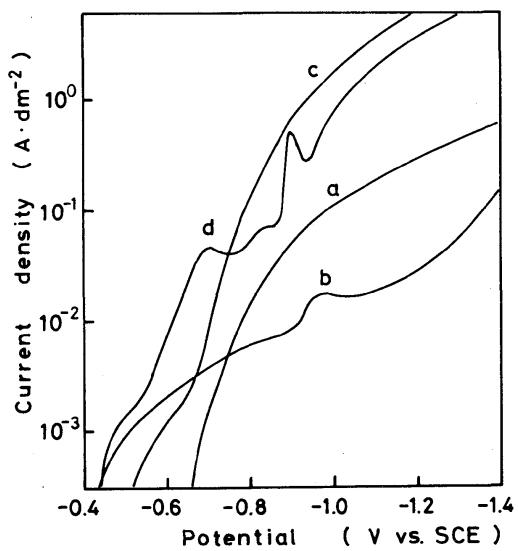

Fig. 2 Cathodic current-potential curves obtained in each solutions on $\mathrm{Pd}$ electrode at $1 \mathrm{mV} \cdot \mathrm{s}^{-1}$.

Solutions ; a : supporting electrolyte, b : $5 \times 10^{-3} \mathrm{~mol} \cdot \mathrm{dm}^{-3} \mathrm{Tl}^{+}$, c: $0.088 \mathrm{~mol} \cdot \mathrm{dm}^{-3} \mathrm{Pd}(\mathrm{en})_{2}{ }^{2+}$, $\mathrm{d}: 0.088 \mathrm{~mol} \cdot \mathrm{dm}^{-3} \mathrm{Pd}(\mathrm{en})_{2}{ }^{2+}+5 \times 10^{-3} \mathrm{~mol} \cdot \mathrm{dm}^{-3} \mathrm{Tl}^{+}$ 
18 クーロン・ $\mathrm{cm}^{-2}$ で作成した。電解液中にタリウムイ オンが存在しない場合, ハラシジウム電析の電流効率は低 く皮膜中に多量の水素が吸蔵されている。このことは, ハララジウムの電析とともに水素が共析してハシラジウムの 電析を抑制するとともに, 皮膜表面で生成した吸着水素 原子が内部に拡散して吸蔵される(19)ことを示している。 一方電解液中にタリウムイオンが存在する場合, ハラジ ウム電析の電流効率が増加するとともに; 皮膜中にタリ ウムが 30 at. \%程度も共析して水素吸蔵量が著しく低下 した。タリウムは水素過電圧が大きく20),21), 吸着水素 原子の生成を抑制する 水素の発生を抑制してハララジウムの電析を促進しその結 果電流効率が増加して水素吸蔵量が著しく低下したと推 測される。

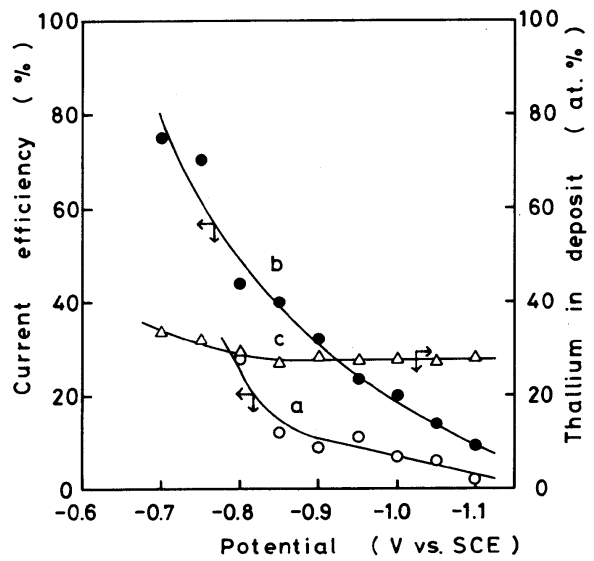

Fig. 3 Current efficiency of electrodeposition of palladium (a, b) and composition of electrodeposits (c). a : $0.088 \mathrm{~mol} \cdot \mathrm{dm}^{-3} \mathrm{Pd}(\mathrm{en})_{2}{ }^{2+}$,

b, c : $0.088 \mathrm{~mol} \cdot \mathrm{dm}^{-3} \mathrm{Pd}(\mathrm{en})_{2}{ }^{2+}$ $+5 \times 10^{-3} \mathrm{~mol} \cdot \mathrm{dm}^{-3} \mathrm{Tl}^{+}$

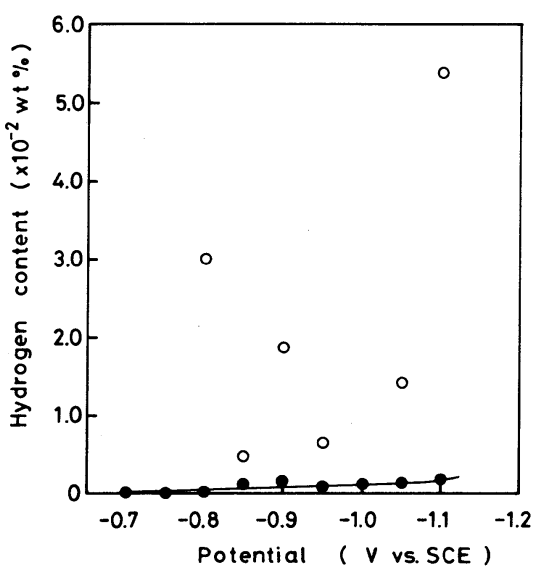

Fig. 4 Hydrogen content of electrodeposits obtained by potentiostatic electrolysis.

: $0.088 \mathrm{~mol} \cdot \mathrm{dm}^{-3} \mathrm{Pd}(\mathrm{en})_{2}{ }^{2+}$,

: $0.088 \mathrm{~mol} \cdot \mathrm{dm}^{-3} \mathrm{Pd}(\mathrm{en})_{2}{ }^{2+}$ $+5 \times 10^{-3} \mathrm{~mol} \cdot \mathrm{dm}^{-3} \mathrm{Tl}^{+}$

\section{3 皮膜の構造や表面形態に対する影響}

図 5 にー $1.0 \mathrm{~V}(\mathrm{SCE}) \cdot 9$ 定電位電解で得られた電析皮 膜のX 線回折図形を示す。各回折線の面指数から電析皮 膜の結晶構造を推定した結果, すべての皮膜が面心立方 格子を有することが判明した。また，タリウムイオンを 含まない電解液から得られた電析皮膜の回折図形に扣け る回折ピークの位置 (b) は JCPDS バラジウム標準図 （a）と一致しているが，タリウムイオンを含む電解液 から得られた電析皮膜の回折ピーク（c）は低角度側に 移行した。回折ピークの位置から算出した結晶の格子定 数も, 電解電位にほぼ関係なく，電析皮膜中へのタリウ ムの共析により执よそ $3.89 \AA$ から $4.07 \AA$ に変化した。 単体のタリウムは，常温に拈いて六方最密格子を有する が，電析皮膜は面心立方格子を有するので，ハラジウム とタリウムは固溶体を形成していると考えられ，結晶格 子点のバラジウム原子がタリウム原子と置換され，その

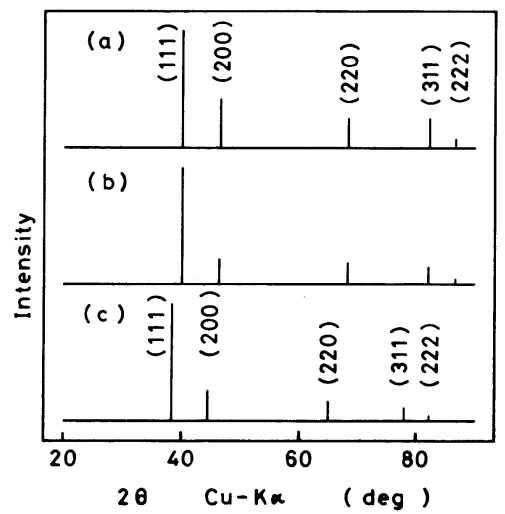

Fig. $5 \mathrm{X}$-ray diffraction patterns of electrodeposits obtained in each solutions at $-1.00 \mathrm{~V}$ (SCE). a : Pd (JCPDS Card), b : $0.088 \mathrm{~mol} \cdot \mathrm{dm}^{-3} \mathrm{Pd}(\text { en })_{2}{ }^{2+}$, c : $0.088 \mathrm{~mol} \cdot \mathrm{dm}^{-3} \mathrm{Pd}(\mathrm{en})_{2}{ }^{2+}+5 \times 10^{-3} \mathrm{~mol} \cdot \mathrm{dm}^{-3} \mathrm{Tl}^{+}$

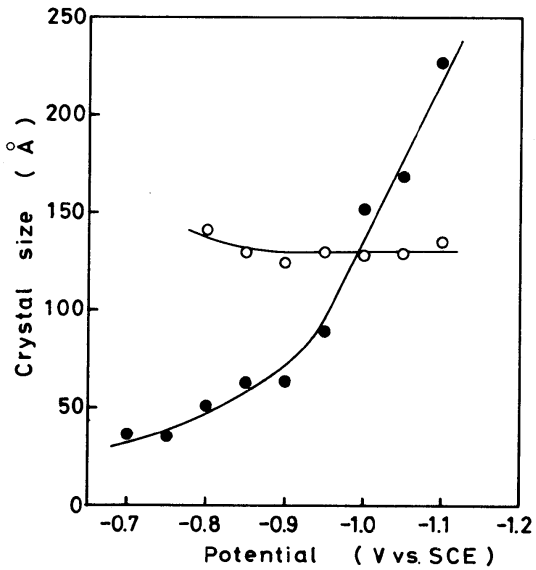

Fig. 6 Crystal size of electrodeposits obtained at each potential.

: $0.088 \mathrm{~mol} \cdot \mathrm{dm}^{-3} \mathrm{Pd}(\mathrm{en})_{2}{ }^{2+}$,

$: 0.088 \mathrm{~mol} \cdot \mathrm{dm}^{-3} \mathrm{Pd}(\mathrm{en})_{2}{ }^{2+}$ $+5 \times 10^{-3} \mathrm{~mol} \cdot \mathrm{dm}^{-3} \mathrm{Tl}^{+}$ 
結果格子定数が変化したと推測される。

図 6 に各電位において定電位電解して得られた電析皮 膜の結晶粒径を示す。タリウムイオンを含まない電解液 から得られた電析皮膜の結晶粒径は, 電解電位が卑にな るとそれに従って $140 \AA ̊$ から $125 \AA$ へとわずかに小さ くなった。しかし，タリウムイオンを含む電解液から得 られた電析皮膜に执いては電解電位により結晶粒径が大 きく変化し, 電位が卑になるにつれ, すなわち過電圧の 増加とともに結晶粒径は $40 \AA$ から $240 \AA$ へと増加した。 図 3 に示すように, 電析皮膜中のタリウム共析量は電解 電位と無関係にほぼ一定であるので, 結晶の大きさは電 析皮膜の組成に依存せず, 過電圧の変化に伴う結晶核発 生速度と結晶成長速度の変化に起因すると思われる。す なわちタリウムイオンによりバラジウム電析の結晶化過 程が変化し, 低過電圧に沶いては吸着あるいは析出して いるものと思われるタリウム原子が結晶核発生の活性サ

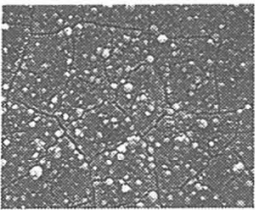

(a)

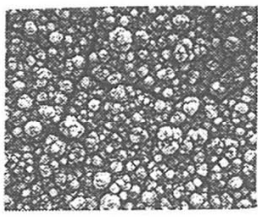

(c)

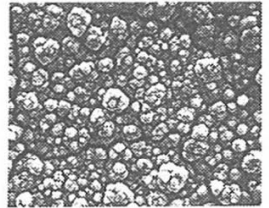

(b)

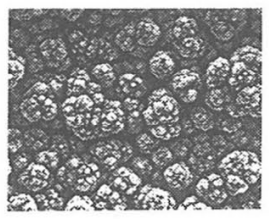

(d)
$5 \mu \mathrm{m}$

Fig. 7 SEM photographs of electrodeposits obtained from $0.088 \mathrm{~mol} \cdot \mathrm{dm}^{-8} \mathrm{Pd}(\mathrm{en})_{2}{ }^{2+}$ solution.

Potential (V vs. SCE) ;

(a) : -0.80 , (b) : -0.90 , (c) : -1.00 , (d) $:-1.10$
イトとなり ${ }^{11)}$ ，核発生が優先的におこるので微結晶の電 析物が得られる。また, 過電圧が増加すると図 1 曲線 $\mathrm{b}$, $\mathrm{d}$ に示すよらにタリウムの通常析出 (overpotential deposition $)^{8)}$ が開始され，析出したタリウムが結晶の 成長反応を促進した結果結晶粒径が増大したと考える。

図 7 にタリウムイオンを含まない電解液からー0.8〜 $-1.1 \mathrm{~V}(\mathrm{SCE})$ で定電位電解して得られた電析皮膜の SEM 像を示す。最も貴な電位で得られた皮膜（a）の 表面には，小さな球状の析出物が存在した。しかし，電 解電位が卑になるに従って皮膜表面の山凸が成長し，無 定形塊状の析出物の存在する黒灰色の粉末状表面へと変 化した（( b )〜（ d ))。また,この電解液から得られた 電析皮膜表面にはすべてクラックが観察された。

図8 にタリウムイオンを含む電解液から各電位に拈い て得られた電析皮膜の SEM 像を示す。タリウムが吸着 または析出しているものと推測されるー0.7 V(SCE) に おいては光沢を持つ平滑な皮膜（a）が電析されたが， 電解電位が卑になるに従って, タリウムイオンが存在し ない場合と同様に表面の凹凸が成長し，球状の析出物の 存在する黒灰色表面へと変化した（( c ）（ e ))。

図 7,8 の電析皮膜表面の変化から, 析出物の形態に 対するタリウムイオンの影響として，次のことが推測さ れる。電解液中にタリウムイオンが存在しない場合には, 電析皮膜中に多量の水素が吸蔵されて内部応力が増大し た結果クラックが生じた。また，共析する水素が電析ハ ラジウム原子の表面拡散を不均一にするため, 塊状の析 出物が形成される。しかし，タリウムイオンが存在する 場合には, タリウムが電極上に析出して水素の発生が抑 制されるので水素吸蔵量が低下してクラックは消隇し， 電析ハララジウム原子の球状拡散 ${ }^{22)} か ゙$ 拈こるため, 析出 物が塊状から球状に変化したと考えられる。

\section{4 タリウムの接触作用}

Mclntyre ら"11)はリウムなどの重金属イオンが電析

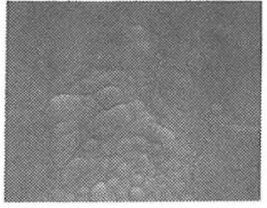

(a)

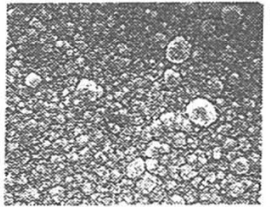

(d)

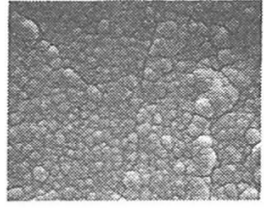

(b)

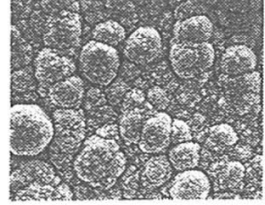

(e)

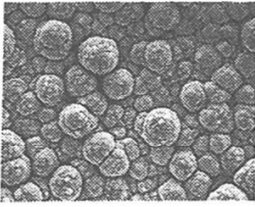

(c)

Fig. $8 \mathrm{SEM}$ photographs of electrodeposits obtained from $0.088 \mathrm{~mol} \cdot \mathrm{dm}^{-3} \mathrm{Pd}(\mathrm{en})_{2}{ }^{2+}+5 \times 10^{-3} \mathrm{~mol} \cdot \mathrm{dm}^{-3} \mathrm{Tl}^{+}$solution. Potential ( $V$ vs. SCE) ;
(a) : -0.70
(b) : -0.80, (c) : -0.90
(d) : -1.00
(e) $:-1.10$ 
に叔よぼす接触作用として，これらのイオンが恐らく吸 着あるいは析出しているものと推測され，かつ単原子層 を形成することにより析出電位を貴に移行 (depolarization）して析出执よび溶解を促進し，また，二次元核発 生の活性サイトになることにより結晶化過電圧を増大さ せ, 結晶核発生と成長の速度に大きな変化を与えること を見い出している。本研究に怙いてもこれらと同様に, タリウムイオンはハララジウムの電析を促進し, 析出電位 を貴に移行させて結晶核発生速度や結晶成長速度を変化 させるなど電極触媒としての作用を示して拉り, タリウ ムイオンがハシラジウムの電析に対して接触作用を示すこ とは明白である。

二次元核発生理論 ${ }^{23)}$ にれば, 結晶核発生速度 $J$ は

$$
\begin{aligned}
J & =\mathrm{K} \exp (-\Delta G / R T)=\mathrm{K} \exp \left(-\pi h \gamma^{2} \mathrm{~V} / R T z \mathrm{~F} \eta\right) \\
& =\mathrm{K} \exp \left(-\mathrm{K}^{\prime} \gamma^{2} / \eta\right) \ldots \ldots \ldots \ldots \ldots \ldots \ldots \ldots \ldots \ldots \ldots \ldots \ldots \ldots \ldots \ldots \ldots \ldots \ldots \ldots
\end{aligned}
$$

で与えられる。ここで $\mathrm{K}, \mathrm{K}^{\prime}$ は定数，クは結晶化過電 圧, $r$ 恃電位の関数である。すなわち結晶化過電圧の増 加が核発生速度を増大させる直接の要因である。図 6 か らもわかるように, 電解液中にタリウムイオンが存在す る場合, 貴な電位に特いて電析皮膜の結晶粒径は非常に 小さく，タリウムイオンが結晶化過電圧を増大させて核 発生速度を大きくしたことは明らかである。また, 結晶 化過電圧は次式で表される

$$
\eta=(R T / z \mathrm{~F}) \ln \left(C / C_{\mathrm{o}}\right)
$$

ここで, $C$ は吸着イオン濃度, $C_{\mathrm{o}}$ は吸着イオン濃度の 平衡値である。この式より, タリウムイオンが存在する 場合吸着イオン濃度が大きくなり, $\operatorname{Pd}(\mathrm{en})_{2}{ }^{2+}$ の吸着が 促進されることは明白となる。

また, 電解液中にタリウムイオンが存在する場合, 電 位が卑になるほど結晶粒径は大きくなるが，この理由は 前述のようにタリウムの析出形式の相違によると考光ら れる。すなわち, 吸着あるいは析出しているものと思わ れる場合と overpotential depositionではタリウム析出 層の構造が異なることが知られて特り ${ }^{8)}$, この構造の相 違がぶラジウム電析の結晶化過程に影響を特よぼすと推 測される。

以上のことから，バラジウムの電析に対するタリウム イオンの接触作用をまとめると以下のようになる。

タリウムイオンはパラジウム上に析出して水素の発生 を抑制するとともに $\mathrm{Pd}(\mathrm{en})_{2}{ }^{2+}$ の吸着を促進し, ハラ ジウム電析の分極曲線を貴に移行して電析を促進する。 また，ハラシジウム上に析出し，ハラジウム電析の活性サ イトとなり, 印加過電圧中の結晶化過電圧を増大させて 結晶核発生を促進した結果結晶を微細化する。そして, 卑な電位になるとともにタリウムの overpotential deposition が開始され, 結晶成長反応が促進されて電 析皮膜の結晶粒径を増大させる。

なお，ハララジウムの電析反応機構におよぼすタリウム のunderpotential deposition については更に検討中で ある。

\section{4. 結}

言

エチレンジアミンパラジウム (II) 錯体溶液からのパ ラジウムの電析に拉よぼすタリウムの影響について検討 し，次のような知見を得た。

タリウムは銅特よびバラジウム上に析出してパラジウ ム電析の分極曲線を約 $100 \mathrm{mV}$ 貴な電位に移行するとと もに水素の発生を抑制し，ハラジウム電析の電流効率を 向上させて水素吸蔵量を著しく減少させた。また, 電析 物の結晶粒径や表面形態を変化させ，電析皮膜に共析し て格子定数を変化させた。すなわち, タリウムはバラジ ウムの電析に対して接触作用を示している。

(1987-2-24 受理)

\section{文献}

1) J.A. Harrison, J. Thompson ; Electrochim. Acta , 18, 829 (1973)

2) A.W. Grobin, Jr., V. Veronesei ; Praktische Metallographie, 18, 181 (1981)

3) R.T. Hill ; Trans. Inst. Met. Fin., 59, 135 (1981)

4) H.D. Hedrich, Ch.J. Raub ; Metalloberfläche, 31, 512 (1977)

5) H.D. Hedrich, Ch.J. Raub ; Surf. Tech., 8, 347 (1979)

6) R.R. Adzic, M.D. Spasojevic, A.R. Despic ; Electrochim. Acta, 24, 569 (1979)

7) S. Swathirajan, S. Bruckenstein ; Electrochim. Acta, 28, 865 (1983)

8) H. Bort, K. Jüttner, W. Lorenz, G. Staikov, E. Budevski ;

Electrochim. Acta, 28, 985 (1983)

9）三国房子, 高村 勉; 電気化学, 37, 852 (1969)

10）三国房子，高村 勉; 電気化学, 38，113（1970）

11) J.D.E. Mclntyre, W.F. Peck, Jr. ; J. Electrochem. Soc., 123, 1800 (1976)

12) S.T. Rao, R.Weil ; Trans. Inst. Met. Fin., 57, 97 (1979)

13）吉村俊一，千田 伸，久保田昇，佐藤栄一；金属表面技術, 36, 359 (1985)

14）千田 伸，久保田昇，佐藤栄一；金属表面技術，38，74 (1987)

15） B.D. Cullity 著, 松村源太郎訳 ; $X$ 線回折要論, p. 301 (アグネ, 1969)

16) W.M. Latimer ; Oxidation Potential Chap.9, p.163 (Prentice-Hall, Inc., Englewood Cliffs, N.J., 1952)

17) L.G. Sillén, A.E. Martell ; Stability Constants of Metalion Complexes, Special Publication, No.17, p.373 (The Chemical Society, London, 1964)

18）千田 伸, 瀬畑浩之, 久保田昇, 佐藤栄一; 金属表面技術, 38, 537 (1987)

19）白鳥 一; 電気化学, 29, 561 (1961)

20) B.W. Conway, J.O.M. Bockris ; J. Chem. Phys., 26, 532 (1957)*

21）喜多英明, 本多正孝; 電気化学, 38，17（1970）

22) N. Ibl, J.L. Puippe, H. Angerer ; Surf. Tech., 6, 287 (1978)

23）日本化学会編；分子レベルからみた界面の電気化学, p.59（学会出版センター, 1978） 